\title{
Sources of Sand and Dust Storms in Kuwait
}

\author{
Raafat Misak*, Abeer H Al Saleh and Ahmed 0 Abdulhadi \\ Department of Earth and Environmental Sciences, Kuwait Institute for Scientific Research, Kuwait
}

*Corresponding author: Raafat Misak, Department of Earth and Environmental Sciences, Kuwait Institute for Scientific Research, Kuwait.

To Cite This Article: Raafat Misak. Sources of Sand and Dust Storms in Kuwait. Am J Biomed Sci \& Res. 2019 - 4(1). AJBSR.MS.ID.000741.

DOI: 10.34297/AJBSR.2019.04.000741

Received: January 25, 2018 | Published: July 12, 2019

\begin{abstract}
In Kuwait, the main threat on highways, oil fields, air bases, military camps, new settlements and agricultural farms is the sand encroachment phenomenon. During June - September 2018, Kuwait experienced severe sand and dust storms. The wind speed reached $70 \mathrm{~km} / \mathrm{hour}$. The northwest wind was prevailing. The sand and dust storms forced the closure of three ports and disruption of air traffic. The visibility was below $300 \mathrm{~m}$. Several incidents were reported along Wafra Roads. Multiple sources of sands and dust storms (SDS) are observed in wide areas in the terrestrial and coastal environments of Kuwait. These sources vary in nature, land use, history, activity, impact and composition. The objective of the current study is to identify and characterize the sources of SDS in Kuwait.To realize this objectives, field surveys were conducted during 2017- 2018. Landsat images of 2010 and 2017 were analyzed for land use comparison.
\end{abstract}

\section{Introduction}

Huge amounts of shifting sands attack highways (Plate 1). Before June 2018, the average amount of removed sands from desert highways was 30,000 m3 /month. During June - August 2018, this average amount increased to $200,000 \mathrm{~m} 3 /$ month (Ministry of Public Works ,2018).

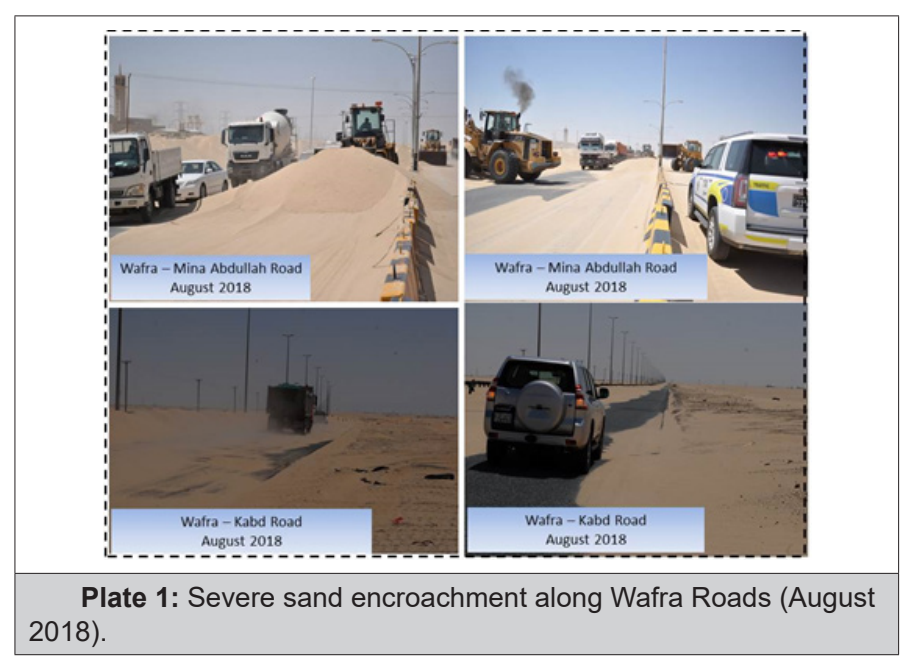

Kuwait is cut by a NW-SE Corridor of shifting sand (Figure 1). The corridor extends in a northwest southeast direction for a distance of $167 \mathrm{~km}$ between Huwaimiliyah Area (at the north) to Wafra Farms (at the south). Its width ranges between $50 \mathrm{~km}$ (upwind side) to $25 \mathrm{~km}$ (downwind side). Several strategic facilities are located in the corridor of shifting sands.These include:

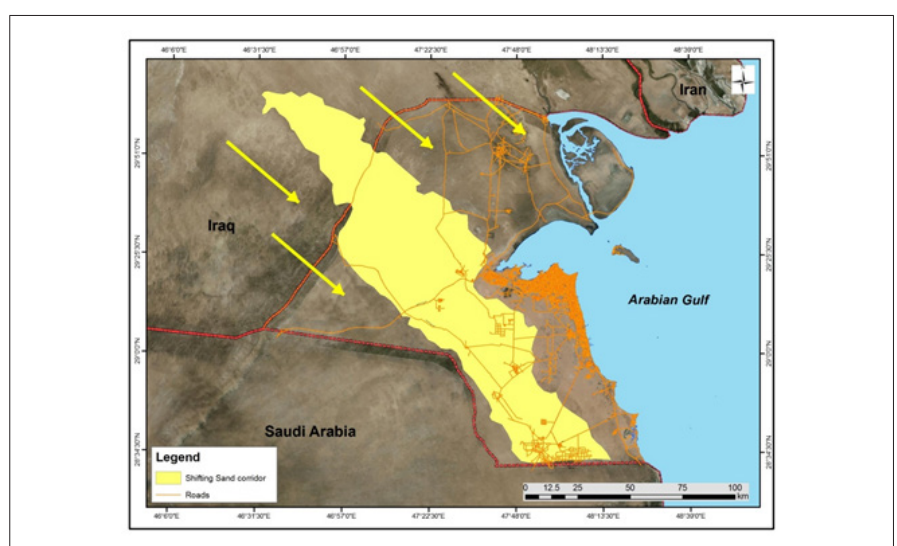

Figure 1: An image showing the corridor of shifting sands. Note the network of highways cutting the corridor.
a. Two air bases (Ali Al Salem and Ahmad Al Jaber).
b. Three oil fields (Burgan, Managish and Wafra)
c. Segments of five highways (Wafra- Mena Abdullah, Wafra- Al Zoor, Wafra -Kabd, Salmi and Ras Sabiyah)

During the period between 2010 and 2017, positive changes in the land use /land cover were noticed (Figure 2). The changes include fencing and protection of two areas of about $119 \mathrm{~km} 2$. These areas which cross the main natural corridor of shifting sands, resulted in its dissection into two portions (Figure 3). Consequently, the recently protected areas act as first defensive line against shifting sands advancing from the north [1]. 


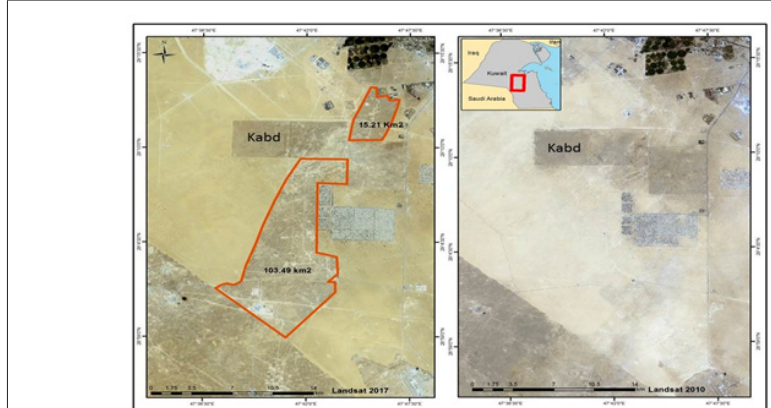

Figure 2: Changes in land use $(2010-2017)$.

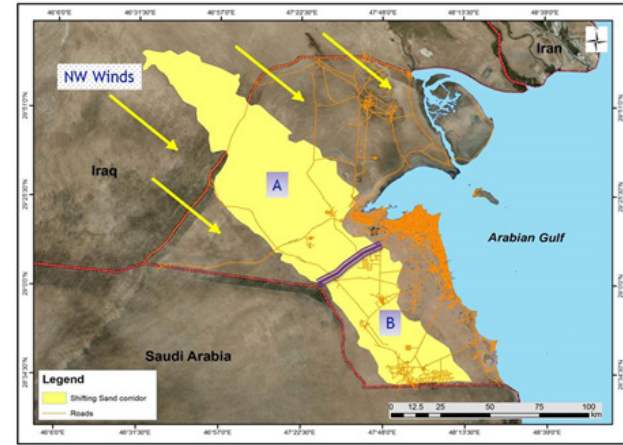

Figure 3: Dissection of the corridor of shifting sands into two portions (A\& B).

\section{Sources of sand and dust storms}

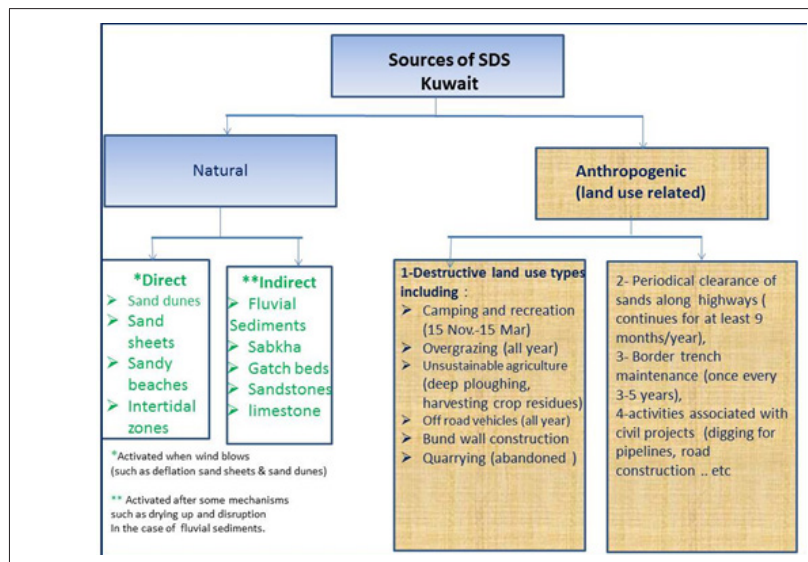

Figure 4: Sources of shifting sands.

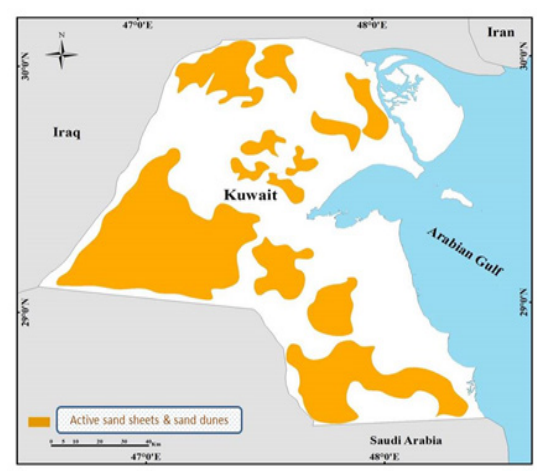

Figure 5: Direct sources of SDS (Sands and Dust Storms) in the terrestrial environment of Kuwait.
Sources of sand and dust storms are classified into two main categories: Anthropogenic (land use related) and natural (Figure 4). The first category is connected to several destructive land use types including overgrazing, off-road vehicles and camping and recreation. The second category of sources is differentiated into two subcategories: direct and indirect. Direct sources are types of sediments/landforms that start drifting when exposed to winds of about $8 \mathrm{~m} /$ second. These sources are widely distributing in Kuwait covering at least $40 \%$ of the country (Figure 5 \& Plate 2).

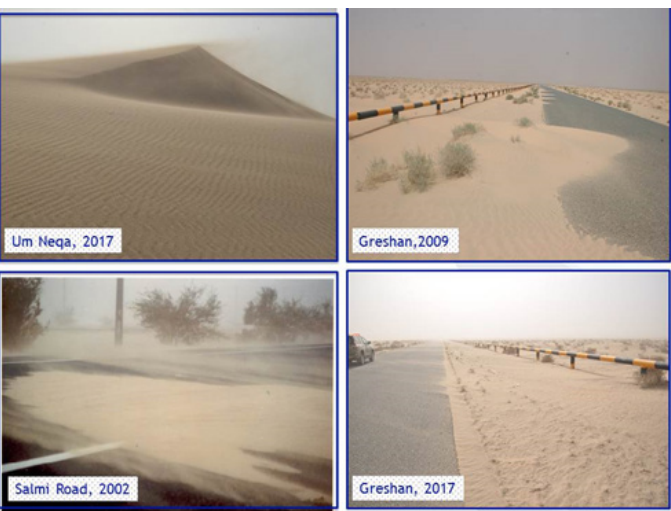

Plate 2: Direct sources of shifting sands (sand dunes and sand sheets).

Indirect sources of SDS are types of sediments that convert to active sources of sand and dust under specific conditions/ mechanisms. Examples of these conditions/ mechanisms are drying up followed by cracking (case of fluvial sediments) and drop of the shallow water table followed by drying up top surface (case of bare sabkha). Some of these conditions are explained in (Table 1) and (Figure 6).

Table 1: Mechanisms of transformation of several types of indirect sources of sand and dust.

\begin{tabular}{|c|c|c|c|}
\hline $\begin{array}{l}\text { Type of } \\
\text { indirect } \\
\text { source }\end{array}$ & $\begin{array}{c}\text { Mechanisms of transfor- } \\
\text { mation }\end{array}$ & Cases & Remarks \\
\hline \multirow{3}{*}{$\begin{array}{l}\text { Fluvial sedi- } \\
\text { ments }\end{array}$} & - Drying up and cracking. & \multirow{3}{*}{$\begin{array}{l}\text { Ritqa -Ab- } \\
\text { daly }\end{array}$} & \multirow{3}{*}{$\begin{array}{l}\text { Observed } \\
\text { after the } \\
\text { floods } \\
\text { of Dec. } \\
2010 \text { and } \\
\text { November } \\
2013\end{array}$} \\
\hline & $\begin{array}{l}\text { - Mechanical breaking and } \\
\text { disruption (off road vehicles } \\
\text { and trampling). }\end{array}$ & & \\
\hline & $\begin{array}{c}\text { - Sand blasts \&deflation } \\
\text { process }\end{array}$ & & \\
\hline \multirow{3}{*}{ Bare Sabkha } & $\begin{array}{l}\text { - Drop of shallow groundwa- } \\
\text { ter table. }\end{array}$ & \multirow{3}{*}{$\begin{array}{l}\text { Wafra - Al } \\
\text { Zour sector }\end{array}$} & \multirow{3}{*}{$\begin{array}{c}\text { remark- } \\
\text { able } \\
\text { emission } \\
\text { of dust, } \\
\text { (June } \\
\text { 2016) }\end{array}$} \\
\hline & $\begin{array}{l}\text { - Dryness and cracking of the } \\
\text { topsoil (few centimeters) }\end{array}$ & & \\
\hline & $\begin{array}{c}\text { - Sand blasts \&deflation } \\
\text { process. }\end{array}$ & & \\
\hline $\begin{array}{c}\text { Concealed } \\
\text { fine textured } \\
\text { soil }\end{array}$ & $\begin{array}{l}\text { Removal /disruption of ar- } \\
\text { mor layer (protective desert } \\
\text { pavement) }\end{array}$ & Abraq-Salmi & \\
\hline $\begin{array}{l}\text { Vegetated } \\
\text { sand sheets }\end{array}$ & Loss of vegetation cover & $\begin{array}{l}\text { Umm Nega } \\
\text {-Sabiyah } \\
\text { sector }\end{array}$ & $\begin{array}{c}\text { observed } \\
2009 \& \\
2017\end{array}$ \\
\hline
\end{tabular}




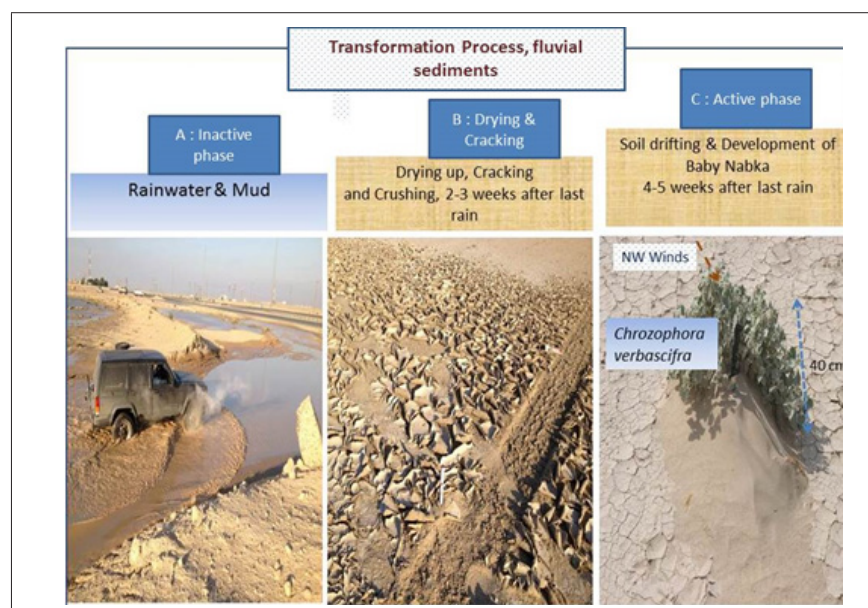

Figure 6: Process of transformation from inactive to active sources of sand and dust.

\section{Summary and Conclusion}

In Kuwait $(17,800 \mathrm{~km} 2)$ a number of sectors are threatened by shifting sands. These include oil, agriculture, defence, ground transportation, Energy and water, Environment and Public Health. Multiple sources of sands and dust storms (SDS) are observed in Kuwait. They cover at last $40 \%$ of the country. These sources are classified into two main categories: Anthropogenic (land use related) and natural.The first category is connected to destructive land use types .e.g, overgrazing. The second category of sources is differentiated into two subcategories: direct and indirect. Direct sources include sand dunes and sand sheets. While the indirect sources are represented by fluvial sediments and sabkhas.

\section{References}

1. Ali Al Hemoud, Ali Al Dousari, Raafat Misak, Mane Al Sudairawi, Adil Naseeb, et al. (2019) Economic Impact and Risk Assessment of Sand and Dust Storms (SDS) on the Oil and Gas Industry in Kuwait. Sustainability 11(200): 1-19. 